\title{
THE IMPACT OF EXCHANGE RATE ON STOCK MARKET INDICES
}

\author{
Mustafa Hasan HAMAD AMEEN 1 \\ Melik KAMIŞLI ${ }^{2}$ \\ Fatih TEMIZEL ${ }^{3}$
}

Received Date (Başvuru Tarihi):

$27 / 04 / 2020$

Accepted Date (Kabul Tarihi):

$5 / 06 / 2020$

Published Date (Yayın Tarihi):

$25 / 06 / 2020$

In the article, the first author is in the role of Corresponding Author.

\begin{abstract}
The relationship between exchange rate and stock indices has risen many eyebrows so far. These two fundamental financial markets have a significant role in international Keywords:

Stock Indices, business all around the globe. Furthermore, exchange rate is one of the most important indicators that rules in the decision-making process in all firms. In order to understand the relationship between the two variables this paper tried to investigate the relationship between

Exchange Rate,

VAR Model exchange rate of USD/TL and BIST-100 index in Turkish stock market. The data have been collected from January 2009 to March 2020 based on monthly data. VAR model is applied in the study to exam the connections between the variables. The findings reveal that there is

JEL Codes:

B21, D53, E44 only a one-way causality between the variables. Nevertheless, the impulse response results show a negative impact from the shocks of each variable to another.
\end{abstract}

\section{DÖVIZZ KURUNUN BORSA ENDEKSLERİ ÜZERINNDEKİ ETKİSİ}

$\ddot{O Z Z}$

Anahtar Kelimeler:

Stok Endeksleri,

Döviz Kuru,

VAR Modeli

JEL Kodlarn:

B21, D53, E44
Dünyada kullanılan para birimleri arasında Amerikan Doları daha sık kullanılmış ve ulusal para olarak kabul edilmiştir. Bu nedenle uluslararası ticarette de yerini almış, bununla beraber ülkelerin borsa endekslerini de etkilemiştir. Bu çalışmanın amacı BIST-100 endeksi ile döviz kurları arasında kısa dönemde bir ilişki olup olmadığını, VAR modeli ile araștırmaktır. Bu amaçla, USD/TL kuru paritesinin BIST-100 endeksine etkisi incelenmiştir. Veri seti olarak 2009 yılının Ocak ayından 2020 yılını Mart ayına kadar aylik veriler kullanılmıștır. Yapılan analiz sonucunda elde edilen bulgulara göre BIST-100 endeksi ile USD/TL kuru arasında tek yönlü nedensellik ilişkisi tespit edilmiştir. Bununla beraber etki-tepki fonksiyonları anlamlı olup her iki değişkenin de birbirlerinden gelen şoklarda negatif tepki verdikleri gözlemlenmiştir.

\footnotetext{
${ }^{1}$ MBA Student, Anadolu University Faculty of Economics and Administrative Sciences, Mustafahasan957@gmail.com, https://orcid.org/0000-0001-7797-5779

${ }^{2}$ Asst. Prof. Dr., Bilecik Şeyh Edebali University, melik.kamisli@bilecik.edu.tr, https://orcid.org/0000-0001-6419-2257

3 Prof. Dr., Anadolu University Faculty of Economics and Administrative Sciences, ftemizel@anadolu.edu.tr https://orcid.org/0000-0002-7208-3293
} 


\section{INTRODUCTION}

In this complicated and noisy world, countries are struggling each other in order to have a strong economy. A strong economy means that the country has strong ability over the other countries around the globe. We have heard a lot of stories regarding to those countries whose economies were in top and then the economy power moved towards prevented. Backing to past, the power was under those hands who had a strong military system, but in today's world, the powerful countries are those with strong economy and they are leading the world. The best gun of their economy is their money and the value of the money. The value of US dollar is the example.

The value of money has been a huge problem for many countries in the last few decades. Despite the strategies that they use to keep the value of their money or make their money stronger, some of them could not be successful to meet their goals and the currency's values decrease time by time. There are some important factors that affect the currency prices either positively or negatively. Interest rate, inflation rate, countries balance of payment and debts, political stability and some other macroeconomic variables that can directly impact the value of money and countries' exchange rate policy. If we look at the impacts of interest rate on the value of money as example. We can see that the higher interest rate leads investors to invest in cash as well as attract more international capital into the country. And then, demand for the currency rises which therefore leads to rise the value of currency. On the ther side, lower interest rate means lower return on cash investment.

The movements in exchange rate make a kind of uncertainty to the company's aspect towards the future and their financial performance regarding to the profit, cashflows, assets and liabilities. Companies that cannot read or lead the foreign exchange risks may suffer more losses, and of course this affects the value of the company and its stock prices. So that, the stock market and the stock market indices are the main reacted indicators that indicate the changes in exchange rate over the company's share price and price indices. The relation between exchange rates and stock market indices has risen many eyebrows during the past years. Many studies 
prove the fact that the value of shares can be affected by the changes in currency prices. It means that, there is a direct relation between the stock market indices and exchange rates. On the other hand, some other researchers investigated that there is no specific relation between the variables.

There are different ideas to identify these relations between them, the popular theory of Doeunbuch and Ficher under the name of "Flow- Oriented model" assumes that the changes in money value or exchange rate changes the company's performance by increasing cost of funds or company's revenue. It is clear that every change in company's cost or revenue affects the firm's stock price either positively or negatively. At the same time, Stock- Oriented model emphasizes the increasing of stock returns by capital assets transaction which roles in rising stock markets. The model states that the increase of demand for domestic currency is the cause of capital flows and then will be a cause to an apricated exchange rate. The perceptions of capital markets will attract foreign investors to come to the country and then will affect the exchange rate of the country.

In the last two decades Turkey has been the trade center for many international companies and the countries in the middle east. Due to its geographical area, it has been said that Turkey is the land of opportunities and growth. And doubtlessly, Turkey has shown its greatness during the last fifteen years. In 2013 Turkey aimed to create the Turkish global trademark as the largest financial center in Eurasia region. From then to now Turkey has seen many developments and could leave its fingerprint in the area. Meanwhile, the fluctuations in Turkish Lira has become the biggest barrier to the economic developments in the region. Due to losing its value against US dollar, Turkish Lira is now not that valuable compared to five years ago, when its value was only 2.5 TL against one US dollar. Meanwhile, for now, the Turkish Lira has lost its value with more than forty percent compared to 2015.

Due to its value and the fluctuations in its exchange rate the Turkish Lira has become a serious threat upon the companies' performance in Turkey and the stock price indices in Borsa Istanbul. This reduction also influenced the revenue of firms and their cost of production. The purpose of the study is to determine the impacts of 
exchange rate on stock market indices. To do that, the exchange rate of TRY against USD and its impact on BIST-100 index have been studied. BIST-100 stock index is ruling in determining the price and return performance of registered stocks in Borsa Istanbul. The current situation is aimed to examine by using the latest available data from central bank of Turkey. The second part of the study is containing the previous studies regarding to the topic, while the data and methodology are placed in part three. Findings and data analysis are positioned in the fourth part. The summary and conclusion part are located in section five with resources in part six. The important characteristics that make this study to be much more different than the studies mentioned in the literature part is that this study takes 10 years data and examines the circumstances during the time period that the study is based on. On the other hand, the data have been chosen between the two global financial crises which they are the 2008 financial crisis and COVID-19 financial crisis. These are the two main reasons that the study relies on. Therefore, we chose data from January 2009 and ends with the first quarter of 2020. In the end of the research we will determine all the impacts that happens due to the fluctuations in exchange rate upon the Turkish stock market during this sensible period.

\section{LITERATURE REVIEW}

The relationship between exchange rates and stock markets may differ from one geographical area to another and it may change from one economy to another. Nevertheless, it may depend upon the internal relations and international conditions. Some studies have shown that due to their nature it might not be easy to determine the influences of these variables. Even the estimation of their direction is differing from one direction to another. These directions can be unidirectional, bidirectional or multidirectional.

A study by Franck and Young (1972) has shown that there is no relationship between both of the variables, the study included six difference exchange rates and the variables were only normal financial variables (Franck \& Young, 1972). Gokçe (2001) used ARCH models to analyze the relation between exchange rate and ISE. The study took advantage from daily data from the values of stock exchange. According to the 
results of the study, daily news can change the direction of the exchange rate, these fluctuating in the exchange rate will positively impact the stock prices and stock indices in ISE (Gökçe, 2001). As Muhammad, Rasheed and Husain applied both of error correction modelling approach and standard Granger causality test by using monthly data from January 1994 to December 2000 to analyze the impacts of exchange rates on stock market returns over four South Asian countries. They proved that no long-run and short-run addiction exists between stock returns and exchange rates for Pakistan and India. Meanwhile, there was a bidirectional causality for long run in Bangladesh and Sri Lanka with no short run changes (Muhammad, Rasheed, \& Husai, 2003). Kasman in the same year stated that exchange rates can impact the stock indices especially on industry sector index. Meanwhile, the researcher gives evidence that there is a stability in long run relationships with time-series techniques between both of the variables (Kasman, 2003). Kim (2003) used monthly data from 1974 to 1998 to investigate the relationship between exchange rate of Dollar and stock prices. He found that there is a negative relationship between the changes in the value of dollar and the S\&P 500 index. And conversely, the long-term relationship is existing in the U.S. financial markets (Kim, 2003).

Ravazzolo and Phylaktis (2005) found that the two variables have a positive relation and US stock market roles as a channel for these connections. Plus, the effects of financial crisis were temporary effects on long-run in these markets (Ravazzolo \& Phylaktis, 2005). Moreover, there are some other empirical studies regarding the exchange rate volatility and its impacts over the security prices. Some macroeconomic variables, namely interest rate, money supply, industrial production and exchange rate consequentially role in expecting market returns, Abugri (2006) examined the roles of mentioned variables over stock returns by having evidence from Latin American markets via applying VAR model to analyze the data, the results show that the international factors such as exchange rate can directly affect the security prices (Abugri, 2006).

A significant causal relationship was reported by Liu, Fok and Pana (2006) over seven East Asian countries including Japan, Malaysia, Hong Kong, Singapore, Korea, 
Thailand and Taiwan. The study aimed dynamic linkages between the variables from January 1998 to October 1998, it stated that the stocks prices and exchange rates are linked together previously from the Asian financial crises. Moreover, there is a casual relation from the equity market to the foreign exchange market in Korea, Hong Kong and Singapore (Pana, Fok, \& Liu, 2006). Due to their behaviours, commodity prices are not stable and more sensitive in short-term times while the exchange rates are strongly forward looking. Chen, Rogoff and Rossi (2008) tried to study whether exchange rates forecast commodity prices or not. They investigated that exchange rates have a strong power in forecasting international commodity prices. That includes both of in and out of sample, and also against different alternative benchmarks (Chen, Rogoff, \& Rossi, 2008). Acikalin, Aktas and Unal (2008) applied VECM over macroeconomic variables such as GDP, interest rate, $\mathrm{CAB}$ and exchange rate by using quarterly data. They found that the mentioned macroeconomic variables have a long-term constant relationship on ISE, moreover, they stated that any change in the determined variables have a unidirectional relationship on the ISE index (Acikalin, Aktas, \& Unal, 2008).

Aydemir and Demirhan (2009) examines the influence of macroeconomic variables on stock indices by using data from Feb 2001 to Jan 2008. Four different stock indices were used in Turkish stock market. The findings of the study illustrate that there is a negative causal relationship between the selected stock indices and exchange rate volatilities (Aydemir \& Demirhan, 2009). Agrawal (2010) used Granger Causality test to analyze the volatility of Indian Rupee against USD exchange rate and its impacts on security returns on India. The results identified a negative correlation relation and a unidirectional relation between the taken variables (Agrawal, 2010). China has one of the strongest economies around the globe. Its financial markets are in top compared to the surrounded countries. Zhao (2010) researched the relations between Renminbi real effective exchange rate and prices of stocks via VAR model and GARCH model by using data from January 1991 to June 2009. The results showed a negative relation between the variables. Moreover, no stable long-term relationships have been noted among determined variables. As well as, the stock markets and foreign exchange rates had no mean spillovers (Zhao, 2010). 
Goods market theory and portfolio balance approach evidenced that the stock indices and exchange rates have influence on each other, Rahman and Zia (2011) tried to analyze the long run relations between stock indices and exchange rate by using Granger Causality test, they proved that there is no long-run relation between the aforementioned variables. The study was depended on the data from Jan 1995 to Jan 2010 and no relationship was found (Zia \& Rahman , 2011). Despite the strong impact of the exchange rates on the stock indices, Groenewold and Paterson (2011) claim that there is a clear gap in our knowledge about the effects of exchange rate on stock prices. Meanwhile there are so many reasons to see the gap. Their study proved that a strong relationship exists between the determined variables. Furthermore, it is mentioned that a change in one variable can change the direction of the other one (Groenewold \& Paterson , 2011). Parsva and Lean (2011) researched the relationship between exchange rates and stock price indices over six Middle Eastern countries like Jordan, Egypt, Kuwait, Iran, Saudi Arabia and Oman from Jan 2004 to Sep 2010. They proved that a bidirectional relation exists between the exchange rate and stock prices in both of the short term and long term for countries like Iran, Oman and Egypt previously from the global financial crisis in 2007. Meanwhile no short-run relations existed for Saudi Arabia and Jordan while it can be seen for Kuwait. Furthermore, the interactions between the markets were increased for all countries expect Iran during the 2007 financial crisis (Lean \& Parsva, 2011). After studying the long and short-run dynamics between exchange rates and stock prices by using Granger causality test to test a group of Pacific Basin countries by collecting data from 1980 to 1998. Savaş and Can used Multiplier Linear Regression and Geanger Casuality tset to examine the relationship between the EUR-USD parity which are traded in IMKB and the stock market indics. According to their data which have been taken from Jan 2007 to Jul 2009 it has been investigated that the exchange rates have a positive influence over the BIST-100 index and the results were supported by the GC test (Savaş \& Can, 2011).

Altin (2014) pointed out that the effects of foreign currencies vary and they can influence securities' volatility in different ways. The result of his study showed that, both of the long run and short run relations will exist when changes happen in exchange rate (Altin, 2014). Suriani, Kumar, Jamil and Muneer (2015) stated that there 
is no relationship between the two variables and they are independent from each other (Suriani , Kumar, Jamil, \& Muneer, 2015). The volatility spillover effects have been examined by Mozumder, Vita, Kyaw, and Larkin (2015) by using EGARCH model. According to the results, the markets are ineffecient informationally and they have interchangable power on each other. The study took three emerging countries and three of developed countries (Mozumder, Vita, Kyaw, \& Larkin, 2015). Exchange rate is one of the determined variables that have effects on stock prices. Saha and Bahmani (2016) used monthly data from countries like Canada, Indonesia, Brazil, Chile. Malaysia, Japan, Mexico, Korea and U.K., they show that changes in exchange rate have asymmetric influences on stock prices but the effects are usually short-term effects. Both of the error-correction modeling and ARDL approach were used to analyze the data in the study (Saha \& Bahmani, 2016). There are some other papers which show that whether the relationship between the variables is positive or not. Another paper which has been done by Umit and Coskun (2016) proves this fact. The study was run by the ADF, PP, Lee-Strazicich and Zivot Andrews root tests, and then both of Johansen and Mki's were used to prove the results of the study. They showed difference results between the Johanson and Maki. According to Johanson's cointegration test the results there were positive relations between the variables for long run time and Maki's test provide no evidence to prove the relationship for long run and short run (Coşkun \& Ümit, 2016).

After analyzing the impacts of macroeconomic indicators by taking example from different variables and testing them over stock markets in fifty difference countries, Uzun and Gungor (2017) determined that a bidirectional relationship exists between the variables and indices in some developed and developing countires. Meanwhile, the impacts of interest rate was exist only in less developed countires with no relations for exchange rate (Uzun \& Güngöre, 2017). Kayaoğlu and Kayaoğlu (2017) examined the low liquidity of stock market and exchange rate volatility. In their point of view, the value of money can affect the security's return. As well as, they claim that by existing illiquidity in a market, the market will lose its economy volatility and the changes reflect to the stock markets and impact its returns (Kahyaoglu \& Kahyaoglu, 2017). By employing ARCH model Basarir (2018) could show that there is a 
relationship between both of the variables, any change in Euro or Dollar can directly change the causality of security's volatility in Turkey's Stock Market. The fluctuations in exchange rate of USD/TRY and EURO/TRY can be the main result over the changes in stock indices especially BIST-100 (Basarir, 2018). Nonetheless, according to their study in (2018) Eyuboğlu and Eyuboğlu have examined the impact of USD and EUR exchange volatilities on BIST 100 indices by using data from 03/01/2011 to 26/05/2016. The ARDAL model was taken to analyze the collected data. The study provided difference results, there were both of long- and short-term relationship between the taken indices and exchange rates between EUR/TRY and USD/TRY. According to Toda-Yamamoto causality test results the tadeonal approach was supposed to be use in Borsa Istanbul (Eyüboğlu \& Eyüboğlu, 2018).

Researching and analizing the relations between macroeconomic variables and the registered stocks in ISE has been topic for many researchers sor far. Soyaslan (2019) ended up a research regarding the two variables (ISE 100 Index and Exchange rates) the data have been collceted from Jan 2015 to March 2018. According to the findings, there was not any cointegration relationship for long run and the variablse did not act each other. Meanwhile, the exchange rate of Euro was found as a small significant level for short run with no changs in US dollar. As a result of the study, the 10 years effect was $15.22 \%$ for Euro exchange rate and $9.44 \%$ for US dollar was found as a long run relationship between the taken variables (Soyaslan, 2019). Demir (2019) suggested that the Istanbul Stock Exchange has to be supported by a stronger national currency and foreign capital flows should be higher with lower investment costs, he investigated that the changes in exchange rate can easily influence the stock market returns (Demir, 2019). Although, Mechri, Ben Hamad, Peretti and Charfi (2019) believe that the volatilities in exchange rate can impact the stock market indices and they give both of Tunisia and Turkey as evidence. They investigated that there is an important relation between the variables and the change in exchange rate affect the stock market indices (Mechri, Ben Hamad, Perttti, \& Charfi, 2019). Zarei, Ariff and Bhatti (2019) have studied the impact of exchange rates on stock market returns by taking seven difference currencies. The study showed that there is an important relation between 
the stock return and the fluctional in currency's exchange rate (Zarei, Ariff, \& Bhatti, 2019).

\section{DATA AND METHODOLOGY}

This study throws light on the impacts of exchange rate on stock market indices in Turkey. Therefore, our study's focus is towards the exchange rate of USD/TRY and BIST-100 index, then will determine the link between the variables. The frequency of data is kept based monthly data that starts from January 2009 to March 2020. The analyzation process starts with data description and ends with variance decomposition between the variables. In short, the stationary status of series has to be discovered when proving the relationship between exchange rate and stock market indices. So that, the Augmented Dickey-Fuller (ADF) ( (Dickey \& Fuller, 1979) is performed to investigate the stationary status of data by determining the unit roots. And then, the Granger Causality test (Granger, 1987) was employed to check the causality relations between the two variables. Afterwards, based on the analyzed data the VAR model was a suitable model to be used in order to set up a causal relationship between the variables. Although, the VAR model can be useful to pretend shocks to the system and trail out the impressions of shocks on the endogenous variables and also predicting. After that, we applied the impulse response and variance decomposition between the data.

\section{DATA ANALYSIS}

In order to show a clear result for all the tests that have been done during the research time, we strongly believe that diversifying results and providing difference sections for each result can give a stronger mean to our study. So that, explaining each step with data table would be our way to get a more reliable result. In the first phase we will describe the data as shown in the table below: 
Table 1. Descriptive Statistics

\begin{tabular}{lccccc}
\hline & Mean & Std.Dev & Skewness & Kurtosis & Jarque_bera \\
\hline BIST-100 & 0.009256 & 0.068629 & -0.025632 & 2.687574 & 0.559662 \\
USD/TL & 0.010274 & 0.034589 & 0.940229 & 7.736175 & $144.9851^{*}$ \\
\hline & & & & \\
\hline
\end{tabular}

In order to understand the data, we tried to describe the time series data first. The BIST-100 index showed mean with 0.009256, standard deviation is 0.068629 with a negative skewness by -0.025632 and a low value of kurtosis was scored. Furthermore, the Jarque-bera of BIST-100 is constrained normally. On the other hand, the descriptive data of USD/TL scored 0.010274 for mean, 0.034589 for standard deviation with a positive skewness 0.940229 and a high kurtosis was recorded in exchange rate of USD/TL by 7.736175. Likewise, the jarque-bera in this variable was not constrained normally at $1 \%$.

Table 2. ADF Unit Root Test

\begin{tabular}{cc|c}
\hline ADF UNIT ROOT TEST & Intercept & Trend\& Intercept \\
\hline BIST-100 & $<0.01$ & $<0.01$ \\
USD/TL & $<0.01$ & $<0.01$ \\
\hline
\end{tabular}

The results of ADF unit root test is useful to run VAR model easily because the time series data is stationary at level by employing both of the intercept and trend intercept.

Table 3. Heteroskedasticity Test

\begin{tabular}{c|c}
\hline \multicolumn{2}{c}{ Heteroskedasticity test result } \\
\hline Prob. & 0.2652 \\
\hline
\end{tabular}

As a common type of assumptions in data, the heteroskedasticity test is applied. The table above shows that the heteroskedasticity exists in the computed model. 
Table 4. Autocorrelation LM Test

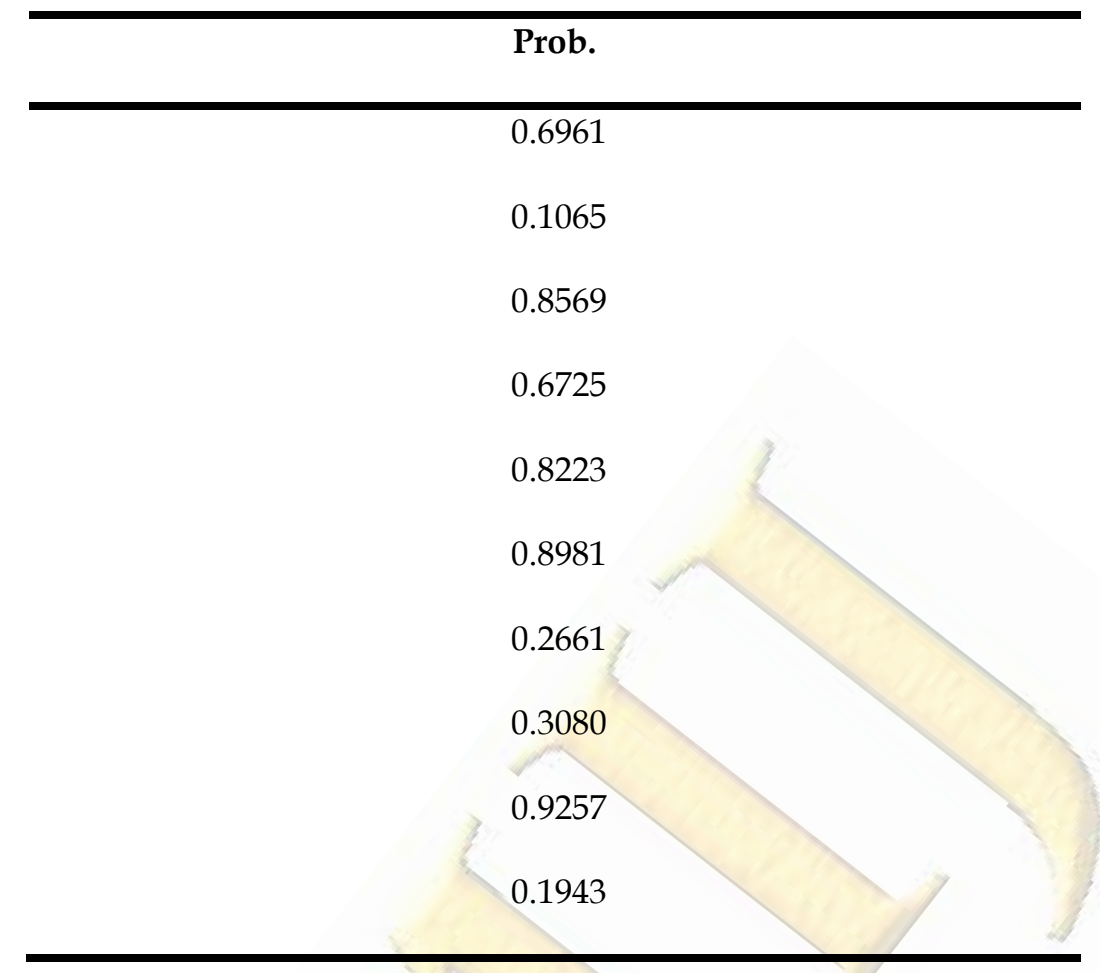

In this phase we employed the Autocorrelation LM test to look at the autocorrelation between the variables. As can be seen in the table above, autocorrelation is existing between all of the variables and they are all greater than $10 \%$. Therefore, it can be said that the time series data is constrained.

Inverse Roots of AR Characteristic Polynomial

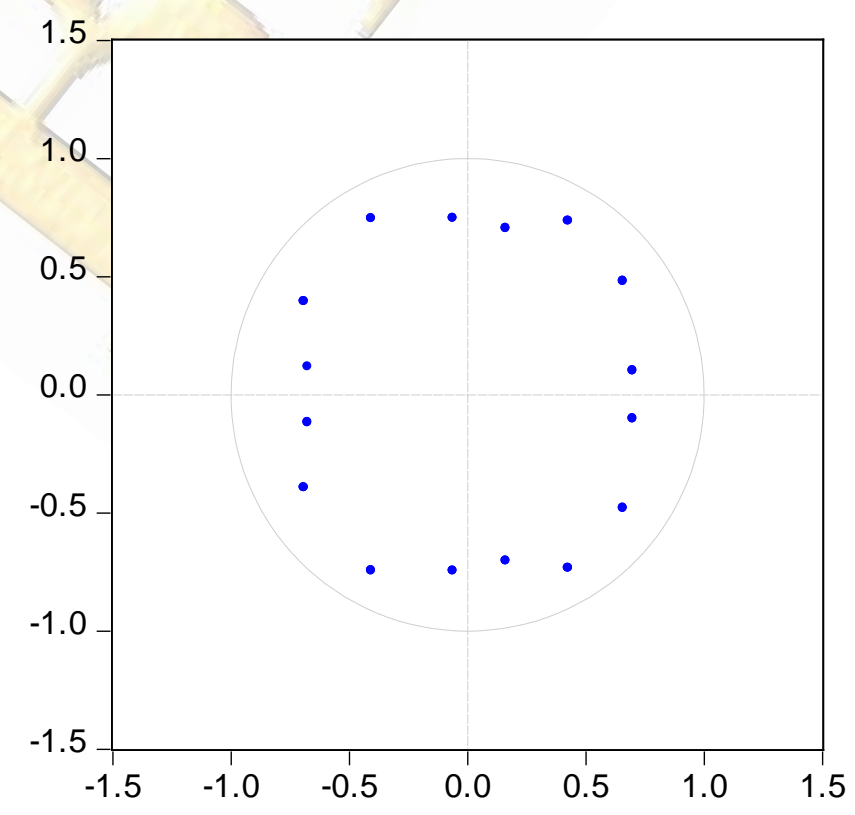

Figure 1. AR Roots Graph 
The figure above is tested by AR roots graph. It provides evidence that data is stationary due to all the roots are located inside the circle. Thus, all the data constrained at VAR (8) model.

It is preferable to employ the Granger Causality test to describe the relationship between the two variables, because all the tests above proved that the time series data is stationary. The table below provides outcomes of Granger Causality test:

Table 5. Granger Causality Test

\begin{tabular}{lc}
\hline & Granger Causality \\
\hline USD/TL $\neq>$ BIST & 0.5851 \\
\hline BIST-100 = > USD/TL & $\mathbf{0 . 0 1 2 2}$ \\
\hline
\end{tabular}

The table above shows that there is no causality from exchange rate of USD/TL to BIST-100 index. Meanwhile, the causality is existing from BIST-100 index to exchange rate of USD/TL. Then, it can be said that there is only a one-way causality between the two variables.

Here, the impulse response is employed to determine the changes in each variable and its impact on the other variables. 
Response to Generalized One S.D. Innovations \pm 2 S.E.

Response of DLBIST to DLBIST

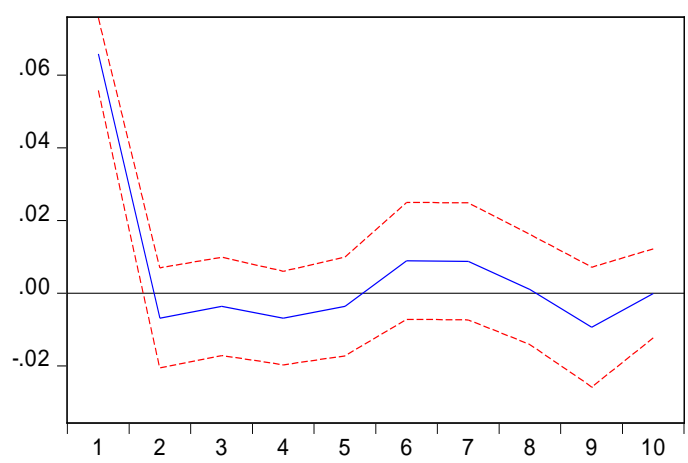

Response of DLUSD to DLBIST

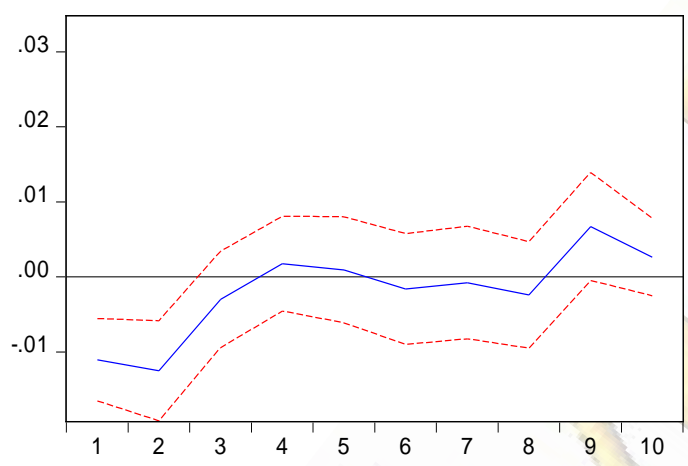

Response of DLBIST to DLUSD

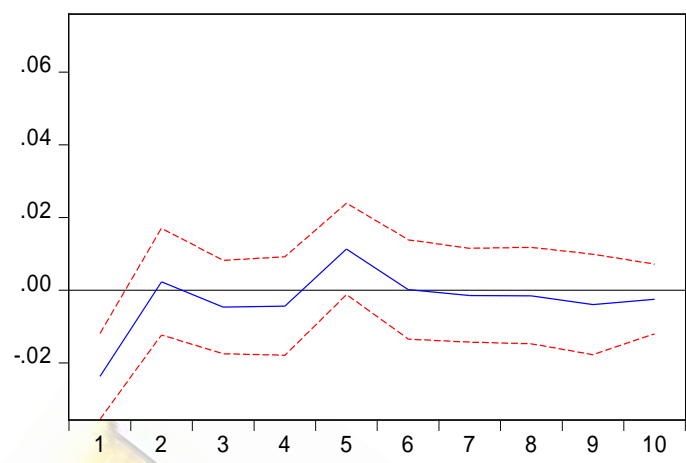

Response of DLUSD to DLUSD

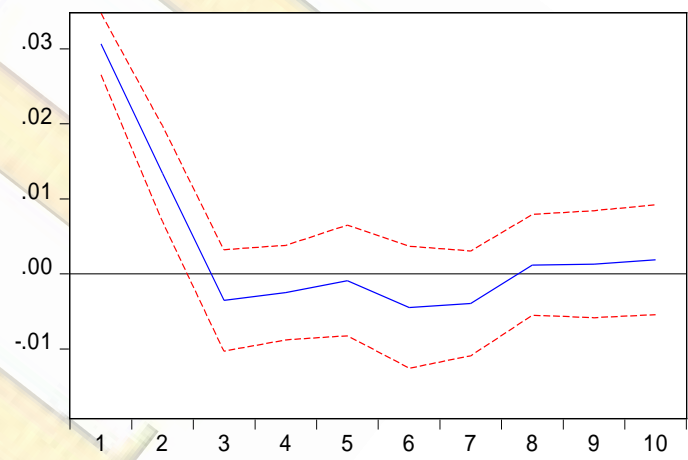

Figure 1. Impulse Response

The first figure investigates that the changes in BIST-100 index can impact itself for two months positively. The second figure demonstrates that any shock in exchange rate of USD/TL can make a negative impact on BIST-100 for one month. Likewise, the shocks that happen in BIST-100 index can create a negative impact on exchange rate of USD/TL for two months. Meanwhile, the shocks in exchange rate of USD/TL make a positive impact on exchange rate itself for three months. Therefore, it can be commented that there is a two-way response between the exchange rate and stock market indices evidenced by the taken variables from January 2009 to March 2020.

The last step in this section is applying the variance decomposition in order to know the variance of variables by determining how much they lagged by their dynamics and other dynamics. 
Table 6. Variance Decomposition

\begin{tabular}{cc}
\hline & BIST-100 \\
\hline BIST-100 Dynamics & USD/TL Dynamics \\
\hline 100.0000 & 0.000000 \\
99.99958 & 0.000420 \\
99.07994 & 0.920058 \\
97.92107 & 2.078933 \\
95.48792 & 4.512084 \\
95.29548 & 4.704517 \\
95.30326 & 4.696742 \\
95.27449 & 4.725512 \\
94.18556 & 5.814438 \\
94.05375 & 5.946246 \\
\hline
\end{tabular}

As can be seen above, BIST-100 is independent variable and its variances with $96.66 \%$ by its own dynamics and contains only $3.34 \%$ dynamics of exchange rate. The table below provides information concerning to exchange rate as independent variable and its variance situation. 
Table 7. Variance Decomposition

\begin{tabular}{cc}
\hline & USD/TL \\
\hline BIST-100 Dynamics & USD/TL Dynamics \\
\hline 12.97788 & 87.02212 \\
23.45703 & 76.54297 \\
23.54927 & 76.45073 \\
23.66827 & 76.33173 \\
23.71597 & 76.28403 \\
23.32452 & 76.67548 \\
22.99142 & 77.00858 \\
23.33809 & 76.66191 \\
25.63635 & 74.36365 \\
25.84590 & 74.15410 \\
\hline
\end{tabular}

The table above shows that exchange rate of USD/TL contains $77.15 \%$ with its own dynamics and $22.85 \%$ of dynamics in BIST- 100 .

\section{CONCLUSION}

This study analyzes the relationship between exchange rate of USD dollar/Turkish lira and stock market indices in Turkey based on monthly collected data from the official website of central bank of Turkey. The time series data start from January 2009 to March 2020. In order to run a reliable VAR model, we first described data and since the time series data are stationary at level in both of the intercept and trend intercept based on ADF unit root test. Then, the Granger Causality test was employed and the results show that there is only a one-way causality between the variables. On other side, the results of impulse response test provide a meaningful relationship between the variables. The two important figures showed that any shocks in one variable can make impact on the other variable for two months negatively. Finally, we employed variance decomposition in order to provide a reliable evidence 
concerning the existing relationship. It shows that both of the variables contain variance with their own dynamics rather than dependent dynamics.

There are different studies investigated the impacts of exchange rate on stock indices from different countries. For instance, (Basarir, 2018) provided the same results as we did. So, it can be an evidence that supports our outcomes. As well as (Kim, 2003) proved that there is a negative relationship between the two variables. So that, it is another support for our results. Meanwhile, some other researches proved that there is no relationship between the exchange rate and stock indices. For instance, (Franck \& Young, 1972) investigated that there is no relationship between the variables. And also, (Suriani , Kumar, Jamil, \& Muneer, 2015) demonstrated that there is no relationship between the taken variables. The reason for that may return to the use of variance exchange rates or difference stock indices than BIST-100. Moreover, the period of the data, the types of currencies and also the methods were used in the study can change the results.

A lot of investors in Turkey believe that changes in exchange rate especially the exchange rate of US dollar and Turkish Lira will cause stock indices and their price whether up or down. For instance, if exchange rate moves up then they predict a move down in stock prices. The cause for this is that the traders will prefer investing their money in foreign currency instead of trading with stocks. Therefore, they will try to sell their stocks in order to buy foreign currencies. In this study, we tried to inspect whether statistical evidences support this presumption or not. The outcomes of the research imply that these variables are linked together and they are not independent from each other. Changes in exchange rate lead the changes in stock prices and vice versa. Therefore, this study can be useful for non-rational investors and they can use it in order to decide more wisely during trading times. 


\section{REFERENCES}

Abugri, B. A. (2006). Empirical relationship between macroeconomic volatility and stock returns: Evidence from Latin American markets. Journal of International Review of Financial Analaysis, 396410.

Acikalin, S., Aktas, R., \& Unal, S. (2008). Relationships Between Stock Markets and Macroeconomic Variables: An Empirical Aalysis of The Istanbul stock Exchange. Journal of Investment Management and Financial Innovations, 8-14.

Agrawal, G. (2010). A Study of Exchange Rates Movement and Stock Market Volatility. International Journal of Business and Management, 67-69.

Altin, H. (2014). Stock Price and Exchange Rate: The Case of BIST-100. European Scientific Journal, 8-9.

Aydemir , O., \& Demirhan, E. (2009). The relationship between stock prices and exchange rates, Evedince From Turkey. International Research Journal of Finance and Economics, 208-213.

Basarir, C. (2018). Volatility Structure of Stock Price Index and Exchane Rates: Casuality Analysis For Turkey. Gümüshane University Electronic Journal of the Institute of Social Science, 342-346.

Chen, Y.-C., Rogoff, K., \& Rossi, B. (2008). Can Exchange Rates Forecast Commodity Prices? National Bureau of Economic Research, 2-47.

Coşkun, Y., \& Ümit, A. Ö. (2016). Türkiye'de Hisse Senedi ile Döviz, Mevduat, Altın, Konut Piyasaları Arasındaki Eşbütünleşme İlişkilerinin Analizi. Business and Economics Research Journal, 47-69.

Demir, C. (2019). Macroeconomic Determinants of Stock Market Fluctuations: The Case of BIST-100. Journal of Economies, 8-9.

Dickey, D. A., \& Fuller, W. A. (1979). Distribution of the Estimators for Autoregressive Time Series With a Unit Root. Journal of the American Statistical Association, 427-431.

Eyüboğlu, S., \& Eyüboğlu, K. (2018). Borsa İstanbul Sektör Eendeksleri İle Döviz Kurları Arasındaki İlişkilerin İnelemesi: ARDL Modeli. Academic Review of Economics and Administrative Sciences, 823.

Franck, P., \& Young, A. (1972). Stock Price Reaction of Multinational Firms to Exchange Realignments. Journal of JSTOR, 66-73.

Gökçe, A. (2001). İstanbul Menkul Kıymetler Borsası Getirilerindeki Volatilitenin ARCH Teknikleri ile Ölçülmesi. Ankara Hacı Bayram Veli University Journal of the Faculty of Economics and Administrative Sciences, 35-58.

Granger, C. W. (1987). Co-Integration and Error Correction: Representation, Estimation, and Testing. The Econometric Scociety, 251-276.

Groenewold , N., \& Paterson , J. E. (2011). Stock Prices and Exchange Rates in Australia: Are Commodity Prices The Missing Link? The University of Western Australia, 4-25.

Johansen, S. (1988). Statistical analysis of cointegration vectors. Journal of Economic Dynamics and Control, 231-254.

Kahyaoglu, S. B., \& Kahyaoglu, H. (2017). Relationship Between Volatility of Stock Market Illiqudity and Exchange Rate Volatility: The Case of Borsa Istanbul. The World of Accounting Science, 10341049. 
Kasman, S. (2003). The relationship between exchange rate and stock prices. Dokuz Eylul University Faculty of Economics and Administrative Sciences Journal, 77.

Kim, K.-h. (2003). Dollar Exchange Rate and Stock Price: Evidence from Multivariate Cointegration and Error Correction Model. Review of Financial Economics, 301-313.

Lean, H. H., \& Parsva, P. (2011). The analysis of relationship between stock prices and exchange rates: Evidence from six middle eastern financial markets. International Research Journal of Finance and Economics, 157-171.

Mechri, N., Ben Hamad, S., Perttti, C., \& Charfi, S. (2019). The Impact of the Exchange Rate Volatilities on Stock Markets Dynamics: Evidence from Tunisia and Turkey . HAL Archives Ouvertes, 28-29.

Mozumder, N., Vita, G. D., Kyaw, K. S., \& Larkin, C. (2015). Volatility Spillover Between Stock Prices and Exchange Rates: New Evidence Across the Recent Financial Crisis Period. Journal of Economic Issues, 43-64.

Muhammad, N., Rasheed, A., \& Husai, F. (2003). Stock Prices and Exchange Rates: Are they Related? Evidence from South Asian Countries. Pakistan Institute of Development Economics, Islamabad, 546-547.

Pana, M.-S., Fok, R. C.-W., \& Liu, A. (2006). Dynamic linkages between exchange rates and stock prices:Evidence from East Asian markets. International Review of Economics and Finance, 503-520.

Ravazzolo, F., \& Phylaktis, K. (2005). Stock prices and exchange rate dynamics. Journal of International Money and Finance, 1031-1053.

Saha, S., \& Bahmani, M. (2016). Do exchange rate changes have symmetric or asymmetric effects on stock prices? Global finance journal, 57-72.

Savaş, İ., \& Can, İ. (2011). Euro-Dollar Parity and Effects of The Real Exchange Rates on The Index of IMKB 100. Eskişehir Osmangazi University Journal of Economics and Administrative Sciences, 323339.

Soyaslan, E. (2019). Döviz Kuru ile BiST Turizm Endeksi Arasındaki İlişkinin Analizi. International journal of society researches, 774-790.

Suriani , S., Kumar, D., Jamil, F., \& Muneer, S. (2015). The impact of exchange rate on stock market. International Journal of Economics and Financial Issues, 1-4.

Uzun, U., \& Güngöre, B. (2017). Borsa Endeksleri İle Ülkelerin Seçilmiş Makroekonomik Göstergeleri Arasındaki Iliş̧kinin Uluslararası Boyutta İncelenmesi. Bolu Abant İzzet Baysal University Journal of Graduate School of Social Sciences, 2-27.

Zarei, A., Ariff, M., \& Bhatti, M. (2019). The impact of exchange rates on stock market returns: new evidence from seven free-floating currencies. The European Journal of Finance , 11.

Zhao, H. (2010). Dynamic relationship between exchange rate and stock price: Evidence from China. Research International Bussiness and Finance, 103-112.

Zia , Q. Z., \& Rahman , Z. (2011). The Causality between Stock Market and Foreign Exchange market of Pakistan. Interdisciplinary Journal of Contemporary Research in Business, 906-919. 